\title{
20th century behaviour of Drygalski Ice Tongue, Ross Sea, Antarctica
}

\author{
M. FREZZOTTI \\ ENEA AMB-CL1M, Casaccia, P.O. Box 2400,00100 A.D. Roma, Italy \\ M. C. G. MABIN \\ Department of Geography, James Cook University, Townsville, Queensland 4811, Australia
}

\begin{abstract}
Drygalski Ice Tongue is the floating seaward extension of David Glacier, a large outlet glacier draining from Talos and Circe Domes of the East Antarctic ice sheet. Several explorers mapped and described Drygalski Ice Tongue in thc early years of the 20th century and, although this information does not allow detailcd intcrpretation of ice-tongue behaviour, it is clear that from 1900-12 it was a significant feature extending $65-75 \mathrm{~km}$ from the coast. More detailed information has been compiled from aerial photographs and satellite images. In December 1956, the ice tongue was about $110 \mathrm{~km}$ long. By December 1957, a major calving event had occurred and the outer $40 \mathrm{~km}$ of the ice congue had broken away. This is the only major 20th century calving event identified, and it may have occurred during a violent storm that affected the Ross Sea area in mid-June 1957. By 1960, further minor ice loss had occurred but, since that time, Drygalski Ice Tongue has maintained the same shape. In January 1993 , the icc tongue was $95.8 \mathrm{~km}$ long and at its terminus was flowing at $880900 \mathrm{~m} \mathrm{a}^{-1}$. Drygalski Ice Tongue is an important regulator of the size of the Terra Nova Bay polynya. The average size of the polynya has varied from nearly $2000 \mathrm{~km}^{2}$, in 1956 , to $650 \mathrm{~km}^{2}$ in 1957 . This has a significant impact on sea-ice production in the Ross Sea. In 1956, about $115 \mathrm{~km}^{3}$ of sea ice would have been produced, sufficient to cover $30 \%$ of the Ross Sea area with a $1 \mathrm{~m}$ thickness of sea ice.
\end{abstract}

\section{INTRODUCTION}

Drygalski Ice Tongue is the seaward extension of David Glacier, the largest outlet glacier in the Victoria Land part of the East Antarctic ice sheet. It drains from Talos and Circe Domes (Drewry, 1983) and covers an area of $224000 \mathrm{~km}^{2}$ (McIntyre; in Swithinbank, 1988).

The ice tongue forms the southern coastline of Terra Nova Bay and plays a crucial role in the persistent development of the Terra Nova Bay polynya. The polynya formation and maintenance are thought to result from the action of the strong persistent offshore katabatic winds that prevent sea ice consolidating in the bay, combined with the blocking effect of Drygalski Ice Tongue that stops sea ice entering Terra Nova Bay from the south (Kurtz and Bromwich, 1985). 'This paper reviews the 20 th century evolution of the ice tongue and its role in polynya development. Data on the positions of Drygalski Ice Tongue and Terra Nova Bay glaciers have been obtained from three types of source: historic maps and descriptions, acrial photographs and maps, and satellite images. Maps and descriptions of the ice fronts are contained in many publications that followed the great exploration journcys of the early 20th century. During these times, the Terra Nova Bay area was visited by the expeditions of Borchgrevink (1900), Scott (1902,
1904 and 1912), Shackleton (1908-09) and Byrd (1940). The available material provides only a general outline of Drygalski Ice Tongue at these times and detailed interpretation of icc-tongue behaviour is not possible. Aerial photographs of Drygalski Ice Tongue were taken by the U.S. Navy in 1956, 1957 and 1960. The 1960 runs were used by the New Zealand Department of Lands and Survey (1965), and the USGS (1968) to compile 1:250000 scale rcconnaissance topographical maps of the area. These were the first modern maps of the area, based on surveyed ground-control points, and sheets SS 58-60/13 (Relief Inlet) and SS 55-57/16 (Mount.Joyce) cover Drygalski Ice Tongue. and David Glacier. Landsat MSS satellite imagery has been available since 1972, Landsat TM images since 1987 and Spot images since 1988. Holdsworth (1985) provided a brief outline of the 20th century history of the ice tongue, pointing to an apparent major change in the icc-tongue shape between 1909 and 1960, and speculating that at least onc calving event had taken place during that time.

\section{THE DRYGALSKI ICE TONGUE-TERRA NOVA BAY REGION}

The David Glacier-Drygalski Ice Tongue area has been described by Frezzotti (1993). The grounding line is 
about $50 \mathrm{~km}$ inland from the coast taken to be a line joining Mount Neumayer and Hughes Bluff) (Fig. 1). The main southern flow from Dome Circe merges with a slower-moving northern flow from Talos Dome (Drewry, 1983). At the coastline the northern flow is moving at $259 \pm 30 \mathrm{ma}^{-1}$, while the southern flow is moving at $580 \pm 30 \mathrm{~m}$ a ${ }^{1}$. However, within a few kilometres the two are flowing at a uniform rate of about $600 \mathrm{~m} \mathrm{a}^{-1}$, increasing to about $880-900 \mathrm{~m} \mathrm{a}^{-1}$ at the snout, with a longitudinal strain rate from $5 \times 10^{-3} \mathrm{a}^{-1}$ to $2.7 \times 10^{-3} \mathrm{a}^{-1}$ (Frczzotti, 1993). These contrasting flow rates are believed to be responsible for the characteristic rifts that open along the northern margin of the ice tongue (Figs 1, 2 and 3). Large areas of multi-year sea ice accumulate along the northern side of the ice tongue. This multi-year sea ice often remains attached to Drygalski Ice Tongue for many years and is carricd out into Terra Nova Bay, giving the ice tongue the appearance of being several kilometres wider than it really is (Fig. l).

\subsection{Drygalski Ice Tongue, $1900-56$}

The first explorer to see the Terra Nova Bay area was Borchgrevink, who sailed through the bay on 7 and 8 February 1900 (Borchgrevink, 1901). From the descriptions and charts in this book, it can be inferred that he sailed along the northern margin of the ice tongue but did not identify it as such.

Drygalski Ice Tongue was first identified and named by Scott, who between 18 and 19 January 1902 sailed into Terra Nova Bay and along the northern margin of the ice tongue (Scott, 1907). On 20 February 1904, he sailed into the bay again, on his homeward journey, and passed the eastern extrcmity of the ice tongue. 'The expedition's cartographer, Mulock, provided the first map of the area which we date to February 1904. It depicts the ice tongue and several prominent peaks in the nearby coastal ranges. These latter are poorly positioned with respect to their relative and absolute locations and have not been used as reference points to estimate ice-tongue length. The ice tongue is shown extending to about $164^{\circ} 55^{\prime} \mathrm{E}$ (Mulock, 1908 . From this information, we deduce that in 1904 the ice tongue was about $73 \mathrm{~km}$ long, and about $15.75 \mathrm{~km}$ wide at its eastern extremity. Mulock's chart also shows a large triangular morphology on the ice tongue to the east of Relief Inlet (Fig. 1) which we interpret as an accumulation of multi-year sea ice, similar to that seen in this area today. The first explorers to traverse Drygalski Ice Tongue were the South Magnetic Pole Party led by David, who crossed the ice tongue from south to north about $20 \mathrm{~km}$ out from the coast (Shackleton, 1909). In February 1909, their ship Nimrod sailed along the northern margin of the ice tonguc before picking them up. From the observations made at these times, Mawson compiled a map of the area (David and Priestley, 1914). In this, the general outlines of the coast and mountain ranges are quite accurate and have been used as reference points from which to estimate ice-tongue length. However, the map shows the ice tongue as having a significantly tapered form, ending in a point rather than the squared-off shape depicted in the Mulock map. This is the outline that was used in all subsequent maps we can locate, until 1960. We consider this outline to be incorrect

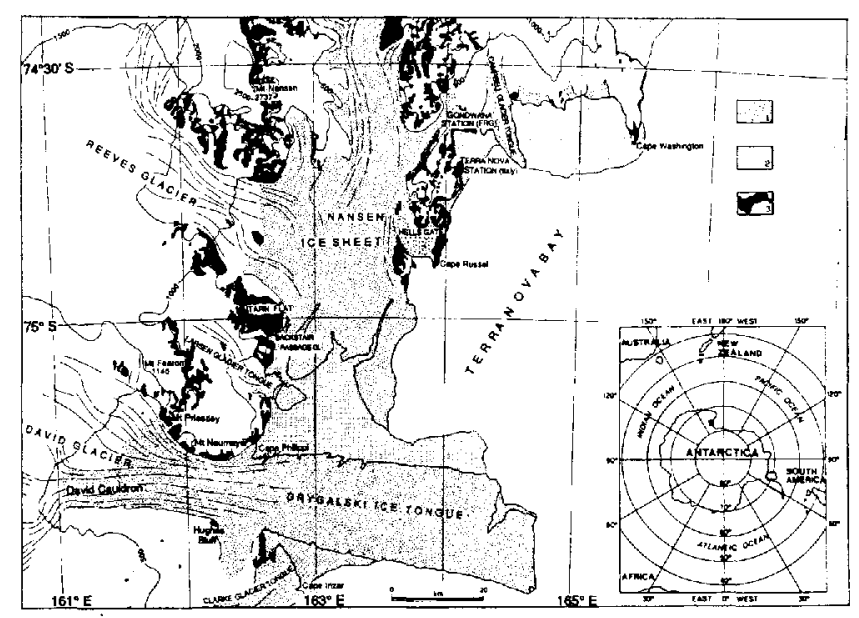

Fig. 1. Map of the Terra Nova Bay region redrawn from USGS 1:250000 topographic maps. 1, floating ice shelves, ice longues and glacier tongues; 2, multi-year sea ice, fast ice and bay ice; 3, ice-free areas.

as it is inconsistent with the 1904 and 1956 outlines, and would require flow rates and calving styles markedly different to those observed since 1956 . The outline of the whole ice tongue could not have been seen from the restricted ground-level views available to the South Magnetic Pole Party; therefore the 1909 outline must have been derived from shipboard observations. However, when the ship was sailing along the northern margin of the ice tongue, the weather was poor with drifting snow (Evans; in Shackleton, 1909). We therefore consider the 1909 map outline of the ice tongue to be incorrect. David and Priestley (1914) gave widths of Drygalski Ice Tongue from the region that the South Magnetic Pole Party had traversed the ice tongue. These indicate that at $37 \mathrm{~km}$ west of the terminus the ice tongue was $24 \mathrm{~km}$ wide, and at $18.5 \mathrm{~km}$ it was $13 \mathrm{~km}$ wide. Based on the relative locations of the details shown on Mawson's map, the ice tongue was about $75 \mathrm{~km}$ long in 1909 . However, the charted longitude of $164^{\circ} 42^{\prime} \mathrm{E}$ for the terminus of the icc tongue makes it about $70 \mathrm{~km}$ long. The tapering shape of the ice tongue we interpret as due in part to accumulation of multi-year sea ice. The unusual calving style postulated by Holdsworth (1985) to fit this shape is considered unnecessary.

The Terra Nova Bay area was subsequently visited in 1912 by a ship and ground party during the second Scott expedition, and again in 1940 during the United States Antarctic Service Expedition under Byrd. However, no useful new cartographic data were obtained. Flights associated with Operation Hijump $(1946-47)$ did not operate in this area.

The map of the ice tongue in 1956 (Fig. 2) was compiled from the TMA 325 photographs using the pcrspective grid technique (Thompson, 1966) and registering detail to the USGS Relief Inlet map. In 1956 , the ice tongue was about $110 \mathrm{~km}$ long and its width tapered irregularly from a maximum of $22 \mathrm{~km}$ at $56 \mathrm{~km}$ from the coast to $13 \mathrm{~km}$ across at the snout. This width is very similar to that shown on the Mulock map of 1904 and the David and Priestley (1914) descriptions, and we suggest that the 1956 shape was essentially the same as 


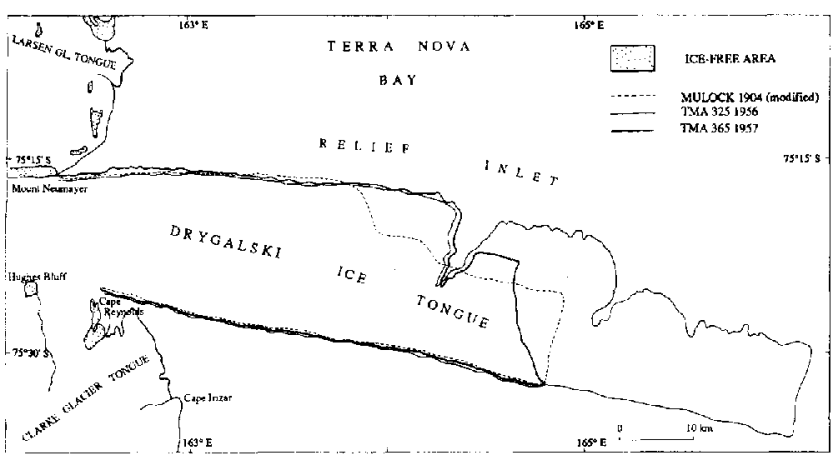

Fig. 2. Drygalski Ice Tongue 1904, 1956 and 1957.

that observed by the carly explorers. Major rifts occurred along the northern margin at 52,82 and $94 \mathrm{~km}$, and multi-year sea ice is attached to about $56 \mathrm{~km}$ from the coast. The Tcrra Nova Bay polynya was also visible, extending out to coincide with the full length of the ice tongue. From 1909 to 1956, Drygalski Ice Tongue had apparently grown $35-40 \mathrm{~km}$ at average rates of $730-$ $830 \mathrm{ma}{ }^{3}$.

\subsection{The 1956-57 calving event}

'The air photographs of December 1957 (TMA 364 and 365) show that Drygalski Ice Tonguc had recently undergone a major calving event (Fig. 2), losing about $40 \mathrm{~km}$ of ice from the end of the tongue, and so producing about $675 \mathrm{~km}^{2}$ of icebergs. The main calving line did not follow any of the pre-existing rifts along the northern side of Drygalski Ice Tongue, although thesc had extended across more than half the width of the ice tongue. However, numerous linear snow-filled depressions cxtend across the ice tongue. We interpret these as the surface cxpression of bottom crevasses, and it appears that the calving line followed one of these depressions. The snout tapered to a point at the southern margin so that Drygalski Ice Tongue was about $68 \mathrm{~km}$ long at the centre of the icc tongue and about $70 \mathrm{~km}$ along its southern margin. The precise date of the calving event is not known and there is no other photography available between December 1956 and December 1957. However, D. H. Bromwich (personal communication, 1987) has identified an unusually severe storm that occurred between 12 and 22 June 1957, and this affected most of the Ross Sea embayment. We interpret this as the most likely direct cause of the Drygalski Ice Tongue calving. Fxamination of air photographs along the length of the western Ross Sea coastline shows that the Campbell Glacier tongue in northern Terra Nova Bay and the Mackay Glacicr tongue $180 \mathrm{~km}$ to the south in Granite Harbour also lost considerable amounts of ice in 1957. Such multiple calving of ice tongues in the Ross Sea area in the space of 1 year has not been recorded since. We consider it likely that the June 1957 storm was responsible for all three ice- tonguc calvings.

\subsection{Drygalski Ice Tongue, 1957-93}

Between the 1957 air photographs and those of October 1960 (TMA 700 and 701) a further small detachment of ice had occurred along the southern terminal part of the ice tongue, which had lost its 1957 tapering form (Figs 2 and 3). $\Lambda$ few tens of $\mathrm{km}^{2}$ of ice were lost, the last noticeable calving of the ice front since 1960. The USGS map of Relief Inlet was constructed from the 1960 air photographs, and shows the ice tongue was about $70 \mathrm{~km}$ long and ended in the charactcristic squared-off shape that it has maintained to the present. Changes in Drygalski Ice Tongue since 1960 (Fig. 3) have been reviewed by Holdsworth (1985) and Jacobs (1987). Frezzotti (1993) used georeferenced Landsat MSS and TM satellite-image data to assess flow rates of the ice tongue. In January 1973 (Landsat 1 MSS, 64/113-114), Drygalski Ice Tongue was about $80 \mathrm{~km}$ long and in December 1988 (Landsat 4 TM, 60/114) it was $92 \mathrm{~km}$ long. A field check in January 1993 showed no significant change in the shape of the ice tongue, which by then was $95.8 \mathrm{~km}$ long. The average velocity of the ice front between 1960 and 1993 was approximately $800 \mathrm{~m} \mathrm{a}{ }^{1}$.

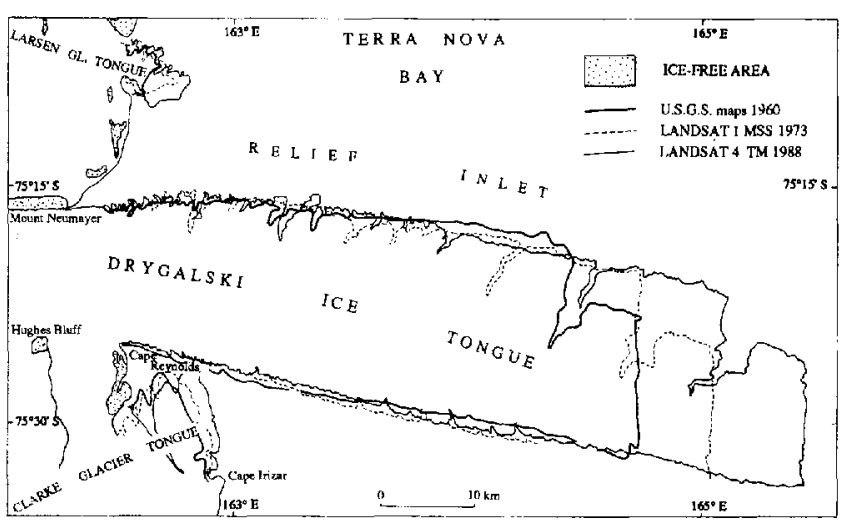

Fig. 3. Drygalski Ice Tongue 1960, 1973 and 1988.

\section{DRYGALSKI ICE TONGUE-TERRA NOVA BAY POLYNYA INTERACTIONS}

Terra Nova Bay is bounded to the north by the slopes of Mount Melbourne, to the west by the Northern Foothills, Inexpressible Island and the Nanscn Ice Sheet, and to the south by the Drygalski Ice Tongue (Fig. 1). The area of the bay as defined here varies with the changing length of Drygalski Ice Tongue, as shown in Figure 4. These calculations omit the areas of fast ice between Cape Washington and Terra Nova Bay station, and multi-year sea ice along the northern margin of the ice tongue. They, show that the bay has varied in size from about $5500 \mathrm{~km}^{2}$ in 1956 , to $1800 \mathrm{~km}^{2}$ in 1957 . A winter polynya, which occupies the western part of the bay, is maintained by a very strong katabatic wind regime Bromwich and Kurtz, 1984). Kurtz and Bromwich (1985) suggested that the length of Drygalski Ice Tongue controls the maximum possible size of the Terra Nova Bay polynya by hindering the transport of sea ice into the bay from the south. Our observations of the polynya and Drygalski Ice Tongue from the air photographs (1956-63) and satellite images (1972-92) support this correlation between the length of the ice tongue and the maximum size of the polynya.

Kurtz and Bromwich (1985) have estimated the mean annual polynya area during 1979 to be about $1300 \mathrm{~km}^{2}$ 


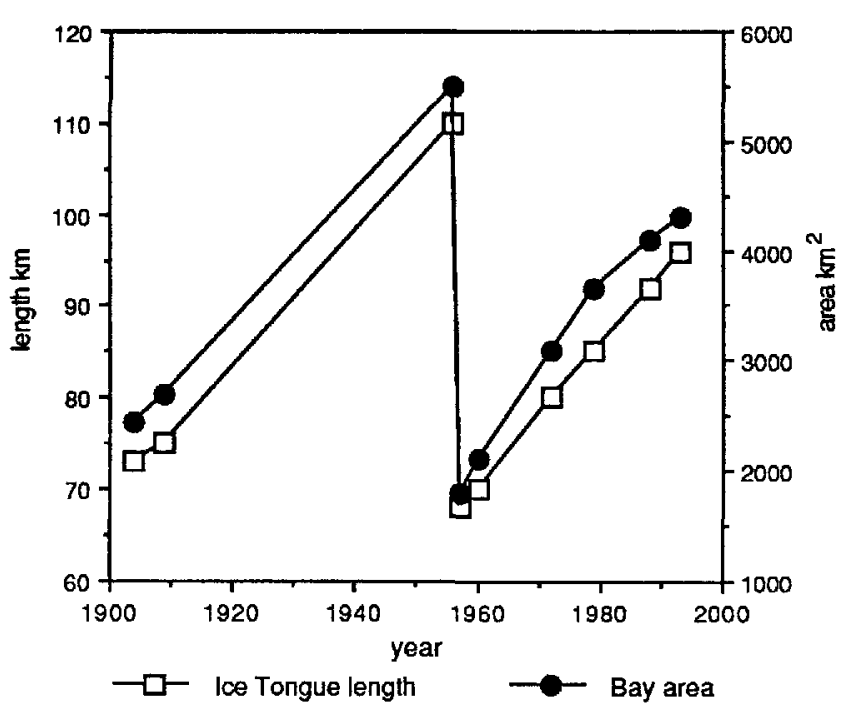

Fig. 4. Variations in the length of Drygalski Ice Tongue and area of Terra Nova Bay during the 20th century.

and this represents about $35 \%$ of the bay area for that year (Fig. 4). As the bay size has varied, we suggest that the average size of the polynya will also have varied. Using the above relationship and the variations in size of the bay (Fig. 4), variations in the size of the polynya can be estimated. Thus, over the 20 th century, the average size of the polynya has probably varied from around $2000 \mathrm{~km}^{2}$ in 1956 to $650 \mathrm{~km}^{2}$ in 1957.

From surface heat-budget calculations, Kurtz and Bromwich (1985) estimated that a cumulative thickness of up to $60 \mathrm{~m}$ of sea ice could have been produced in 1979 . This gave a production of sea ice in the polynya of approximately $78 \mathrm{~km}^{3} \mathrm{a}^{-1}$, which would have been sufficient to cover $20 \%$ of the Ross Sea area (lying southwest of a line from Cape Adare to Cape Colbcck) with $1 \mathrm{~m}$ of sea ice (Kurtz and Bromwich, 1985). Applying these data to our estimated variations in polynya size, wc calculate a possible minimum value of sea-ice production of about $38 \mathrm{~km}^{3}$ in 1957 and a possible maximum of $115 \mathrm{~km}^{3}$ in 1956 . These figures represent $10 \%$ and $30 \%$, respectively, of the coverage of the Ross Sea with a thickness of $1 \mathrm{~m}$ of sea ice.

\section{CONGLUSION}

Examination of historic maps and records, aerial photographs and satellite images has enabled us to determine a reasonably complete history of the 20 th century behaviour of Drygalski Icc Tongue. This is one of the longest such records for an Antarctic glacier, and shows Drygalski Ice Tongue has maintained an essentially uniform shape over the 20th century, with the only major calving event occurring in 1957 when the outer $40 \mathrm{~km}$ of the ice tongue brokc away. The averagc velocity of the ice front bctween 1909 and 1956 was apparently $730-830 \mathrm{~m} \mathrm{a}^{1}$; this is consistent with rates observed from 1960 to 1993 and the longitudinal strain rate $(5-2.7 \times$ $\left.10^{-3} \mathrm{a}^{-1}\right)$ and the flow rate $\left(900 \mathrm{ma}^{1}\right.$ in the period 1988 90) of the terminal part of the ice tongue.

Variation in the size of the Terra Nova Bay polynya has a significant impact on high-salinity shelf water (HSSW) and sea-ice production in the Ross Sea. Surface heat-budget calculations show a possible minimum value of sea-ice production of about $38 \mathrm{~km}^{3}$ in 1957 and a possible maximum of $115 \mathrm{~km}^{3}$ in 1956 . Bottom melting freezing below ice shelves and ice tongues in Terra Nova Bay are linked to deep circulation led by dense saline water (HSSW) formed as a result of salt rejection during sea-ice formation (Baroni, 1990; Souchez and others, 1991; Frezzotti, 1993). Thus, variations in sea-ice production rates that occur with changes in the size of the Terra Nova Bay polynya will also influence the dynamics of this bottom freezing-melting phenomenon.

\section{ACKNOWLEDGEMENTS}

The results presented in this paper were obtained by research efforts supported in part by "Programma Nazionale di Ricerche in Antartide" ITALIANTARTIDE. Archive research by M.G.C. Mabin was supported by the Byrd Polar Research Center, The Ohio State Lniversity, U.S.A.

\section{REFERENCES}

Baroni, C. 1990. The Hells Gate and Backstairs Passage ice shelves, Victoria Land, Antarctica. Mem. Sor. Geol. Ital., 43, 123-144.

Borchgrevink, C.E. 1901. First on the Antartic continent. London, G. Newnes and Co.

Bromwich, D. H. and D. D. Kurtz. 1984. Katabatic wind forcing of the T'erra Rova Bay polynya. 7. Genphys. Res., 89(C3), 3561-3572.

David, T. W. E. and R. E. Priestley. 1914. British Antartic Expedition 1907 9. Reports on the Scientific Investigations. Geology. Vol. 1. London, William Heinemann.

Drewry, 1).J., ed. 1983. Antarctica: glacinlogial and geophysical fotio. Cambridge, Lniversity of Cambridge. Scott Polar Research Institute.

Frezzotti, M. 1993. Glaciological studies in T'erra Nova Bay, Antarclica, inferred from remote sensing analysis. Ann. Glaciol., 17, 63-71.

Holdsworth, G. 1985. Some effects of ocean currents and wave motion on the dynamics of floating glacier tongues. Antart. Res. Ser, 43, 253-271.

Jacobs, S.S. 1987. Ice fronts and icebergs in Ross and Weddell seas. Antart. 7. U.S., $22(5), 9194$.

Kurt\%, D. D. and D. H. Bromwich. 1985. A recurring, atmospherically forced polynya in Terra Nova Bay. Antart. Res. Ser., 43, 177-201.

Mulock, G. F. A. 1908. The charts of the "Discovery" Antartic Expedition 1901-1904. London, Royal Gcographical Socicty, Edward Stanford.

Scot, R. F. 1907. The royage of the "Discovery". London, Macmillan.

Shackleton, E. H. 1909. The heart of the Antarctic. London, William Heinemann.

Souchez, R.M. and 8 others. 1991. Ice composition evidence of marine ice transfer along the bottom of a small Antarctic ice shelf. Geophys. Res. Lett., $18(5), 849852$.

Swithinbank, C. 1988. Satellite image atlas of glaciers of the world Antarctica. L.S. Geol. Sur. Prof. Paper 1386-B, 1-138.

Thompson, M.M., ed. 1966. Manual of photogrammetry. Vol. 2. Menasha, WI, American Society of Photogrammetry.

The accuracy of references in the text and in this list is the responsibility of the aulhors, to whom queries should be addressed. 